\title{
AFECÇÕES, ARTE E EDUCAÇÃO: \\ ALUNOS DA REDE MUNICIPAL DE SÃO PAULO EM ENCONTROS COM QUATRO ILUSTRAÇÕES DO QUADRINISTA RAFAEL SICA
}

Lilian dos Santos Silva*

\begin{abstract}
RESUMO: Este artigo apresenta desdobramentos de uma atividade realizada com 150 alunos de $1^{\circ}$ a $9^{\circ}$ ano da rede municipal de São Paulo, em meio à pandemia de covid-19, em 2020. A partir de uma filosofia da imanência, tal proposta tem como operador conceitual a perspectiva deleuzo-guattariana de afecções - atravessamentos que cingem corpo e mente, ao mesmo tempo. Disparada pelo horizonte de pensamento de Deleuze e Guattari, a atividade aciona um território com a arte, lançando mão de quatro ilustrações do quadrinista Rafael Sica que, reunidas, instauram uma ambiência. Nelas, um personagem está em lugares em que uma profusão de elementos o cerca, ao passo que ele parece ignorá-los. Considerando-se alunos e imagens como forças, forjam-se encontros e perscrutam-se efeitos que daí despontam. Para captá-los, algumas provocações são lançadas aos estudantes. A iniciativa explora, desse modo, o que pode acontecer ao se promover um contato com uma experimentação com ilustrações. Assim, instigando o ato de pensar (na perspectiva deleuziana) e modos de sentir, sondam-se possibilidades de afecções. Sob esse viés, após exibir a proposta, o artigo ressalta a consecução da atividade compartilhando produções dos alunos acerca da experimentação a fim de difundir agitações que elas vertem e potenciais que carreiam.
\end{abstract}

PALAVRAS-CHAVE: Deleuze e Guattari; afecções; educação; arte; alunos.

\section{AFFECTIONS, ART ET ÉDUCATION: \\ ÉTUDIANTS DU RÉSEAU MUNICIPAL DE SÃO PAULO EN RENCONTRE AVEC QUATRE ILLUSTRATIONS DU DESSINATEUR RAFAEL SICA}

\begin{abstract}
RÉSUMÉ: Cet article présente les développements d'une activité réalisée avec 150 étudiants de la $1^{\text {re }}$ à la 9e année du réseau municipal de São Paulo (système éducatif brésilien), en pleine pandémie de covid-19, en 2020. Basée sur une philosophie de l'immanence, cette proposition a comme opérateur conceptuel la perspective deleuzoguattariane des affections - des croisements qui englobent à la fois le corps et l'esprit. Suivant l'horizon de la pensée de Deleuze et Guattari, l'activité déclenche un territoire avec l'art, apportant quatre illustrations du dessinateur de bande dessinée Rafael Sica qui, ensemble, créent une ambiance. Dans ces illustrations, un personnage se trouve dans des endroits où une profusion d'éléments l'entoure, alors qu'il semble les ignorer. Considérant les étudiants et les images comme des forces, les rencontres sont établis et les effets qui en découlent sont explorés. Pour les capturer, des provocations sont lancées aux étudiants. L'initiative explore, de cette manière, ce qui peut arriver lors de la promotion du contact avec une expérimentation avec des illustrations. Ainsi, en suscitant l'acte de penser (dans la perspective deleuzienne) et les manières de ressentir, les possibilités d'affections sont sondées. Sous ce biais, après avoir présenté cette proposition, l'article met en lumière la réalisation de l'activité en partageant les productions des élèves sur l'expérimentation afin de diffuser les agitations qu'elles ont et les potentiels qu'elles portent.
\end{abstract}

MOTS-CLES: Deleuze e Guattari; affections; éducation; art; étudiants.

\footnotetext{
* Mestre em educação pela UNIFESP, Universidade Federal de São Paulo, doutoranda no programa de pós-graduação da FEUSP, Faculdade de Educação da Universidade de São Paulo. E-mail: li1207@gmail.com, Orcid 0000-0002-9889-3710
} 


\section{Notas de abertura - filosofia da imanência na educação: uma possibilidade}

Produções do filósofo francês Gilles Deleuze assim como de Deleuze em companhia de Félix Guattari têm sido acionadas por pesquisas em diversas áreas, como mostram apresentações de trabalhos em eventos acadêmicos ${ }^{1}$. Pesquisadores que se dedicam à geografia, matemática, arquitetura, dança, entre outros campos de investigação ${ }^{2}$, vêm mobilizando discussões a partir destes referenciais. Tais tessituras ressaltam possibilidades de aliança e de conexão com o pensamento deleuziano e deleuzo-guattariano que, por movimentos como este, segue se espraiando.

No que tange à educação, não é diferente; inclusive, o acionamento dos autores tem se intensificado neste campo nas últimas décadas (VINCI, 2014; VINCI; RIBEIRO, 2013). A incidência de Deleuze e Guattari na área a aproxima de uma filosofia da imanência, perspectiva que refrata recognição e representação. Enquanto estas vertentes remetem a modos de fazer e de pensar circunscritos em modelos e em percursos preestabelecidos, aquela abarca possibilidades imponderáveis. Uma filosofia da imanência (DELEUZE, 2002a) atenta à dimensão de uma experiência possível, ao momento presente; como o próprio nome diz, ela contrasta com um aspecto transcendente, com o mundo das ideias ligado ao platonismo. Tal filosofia enaltece encontros de forças e experimentações que não requerem ou prescrevem pontos de chegada.

Por essa via teórica, não é apropriado falar em sujeitos do conhecimento e objetos de pesquisa; privilegia-se trabalhar com forças. Para Deleuze e Guattari (2010), o que há são forças; opera-se com uma perspectiva de forças, intensidades, contatos e contágios. Com isso, o que está em jogo são movimentos, pois tais forças, ao se encontrarem, podem afetar umas as outras e produzir efeitos imprevisíveis a priori. Nossa temática de interesse neste campo se debruça sobre certo "desembrulhar" da educação, considerando, por exemplo, o que se passa em uma aula ou em uma atividade - ali, naquele momento em que ela acontece. Tal recorte vai ao encontro desta mirada teórica, uma vez que ela oportuniza perscrutar desdobramentos de forças dispostas em vizinhança.

Acerca destes contornos, merecem menção três indícios com os quais nos deparamos. Primeiro: ao afirmarmos que a intersecção destes autores com o campo tem se dado em maior vulto, referimo-nos tão somente ao meio acadêmico, ao passo que parece não haver muita repercussão do pensamento da dupla no âmbito escolar. Segundo: nota-se que, ao explorar temáticas educacionais pelo prisma deleuziano e deleuzo-guattariano, parte destas investigações em nível superior consiste em pesquisas teóricas. Terceiro: diante da afluência de estudos desta ordem, reporta-se um comentário que

\footnotetext{
${ }^{1}$ III Colóquio Variações Deleuzianas: corpo entre Filosofia e Arte e Educação..., realizado via Google Meet, em novembro de 2020, e VII Encontro GT Deleuze e Guattari - pensar em veredas que se bifurcam: clínica, política, técnica, educação, arte, literatura -, transmitido pelo YouTube e realizado em dezembro de 2020. A partir de nossa participação neste último evento que foi feito o convite para a publicação deste artigo.

${ }^{2}$ Seguem os links das programações dos eventos referenciados:

$<$ https://variacoesdeleuze.wixsite.com/iicoloquio/comunica $\% \mathrm{C} 3 \% \mathrm{~A} 7 \% \mathrm{C} 3 \% \mathrm{~B} 5$ es-e-apresenta $\% \mathrm{C} 3 \% \mathrm{~A} 7 \% \mathrm{C} 3 \% \mathrm{~B} 5 \mathrm{es}-$ artist?lang $=\mathrm{pt}>,<$ https://www.youtube.com/playlist?list=PLrU4lukqiYq2gXz8jAClwtuH6wQzaaIUi $>$
} 
fortuitamente é emitido em eventos acadêmicos amplos desta área ${ }^{3}$ por pesquisadores que perseguem outras linhas teóricas. Trata-se da apreciação de que trabalhos como esses, grosso modo, concentram-se em fomentar discussões sem, no entanto, propor inferências ao transcurso educacional pragmático; não preconizam algo "para que" se opere de outra maneira, resoluções, saídas. Quanto à procedência ou não dessa argumentação, salientamos que os referenciais deleuzianos e deleuzo-guattarianos, com efeito, não têm propensão a delinear propostas. Contudo, toma-se nota de um viés crítico dessa fala para, em um deslizamento, oferecer uma resposta - o que se faz por meio da presente iniciativa.

Os três indícios fornecem pistas; reúnem vestígios de um incômodo e uma chance de um salto. Tramando urdir incursões teóricas deleuzo-guattarianas a uma laboração prática, ensaiaram-se meios de levar o pensamento dos autores ao ensino fundamental como estímulos a movimentações de aula. Já se tateava tal empreitada quando, no início do ano letivo de 2020, a circunstância pandêmica deflagrou uma condição sine qua non para a iniciativa ser efetivada.

A pandemia de covid-19 impôs (e continua impondo) à educação uma série de desafios ${ }^{4}$. Para evitar a propagação desenfreada do vírus e preservar vidas, escolas foram fechadas e aulas presenciais deslocadas a plataformas virtuais. Diante da urgência em manter isolamento social, na rede pública acentuam-se questões imperativas: parte dos estudantes enfrenta dificuldades de acesso a internet e a dispositivos eletrônicos, e alguns lidam ainda com a defasagem de ambiente doméstico propício às aulas, às atividades e aos estudos, impasses que sobrecarregam ainda mais esses desafios.

Não obstante, este é apenas um enfoque tendo em vista a educação. Esta conjuntura excepcional transborda muito além; arrebata corpos e mentes, confrontando e pressionando-os a situações-limite. O medo do acometimento pelo vírus, as infindas consequências disso, o risco da morte, as perdas consumadas. O desencadear sucessivo de atravessamentos sensíveis como esses fez a proposta que vinha sendo arquitetada ganhar impulso. Desse modo, considerando-se o momento inédito, extremamente delicado e em tal grau adverso, articulou-se uma atividade que dá vazão a modos de sentir e sustenta uma abertura ao que alunos têm a dizer. Para tanto, ela promove uma experimentação com arte e tem como operador conceitual a perspectiva deleuzo-guattariana de afecções (DELEUZE; GUATTARI, 2012, 2010), atravessamentos que, de uma vez, cingem corpo e mente.

Posto isso, este artigo apresenta desdobramentos desta proposta que foi realizada de julho a setembro de $2020 \mathrm{com}$ alunos de $1^{\circ}$ a $9^{\circ}$ ano da Escola Municipal Comandante Gastão Moutinho, localizada na zona norte da cidade de São Paulo. O texto organiza-se em duas partes. Começa delineando a atividade para, na sequência, compartilhar efeitos que daí despontam. Com isso, a segunda parte traz produções dos alunos disparadas pela iniciativa, a partir das quais se tecem algumas análises. Em meio a

\footnotetext{
${ }^{3}$ Como ocorreu no I e no II Encontro do Programa de Pós-graduação da FEUSP, em novembro de 2018 e março de 2020.

${ }^{4}$ À época em que este artigo é escrito - março de 2021 - completa-se um ano da primeira morte registrada em decorrência do coronavírus no Brasil, ao mesmo tempo em que se contabilizam as piores médias diárias de mortes por causa da doença até agora, somando-se 320 mil vidas perdidas.
} 
essas falas, costuram-se esforços que foram efetuados para uma fluência da proposta na trilha de uma filosofia da imanência e de perspectivas de Deleuze e Guattari. Este texto dedica-se, portanto, à correnteza movida por esta atividade.

\section{Proposta: imagens, ambiência, encontro, experimentação}

Lançada a 21 salas de aula da escola, a atividade foi efetuada, ao todo, por 150 alunos. Haja vista a quantidade média de trinta alunos por sala, se o conjunto ou a maioria deles a tivesse realizado, o número de participantes seria bem maior. Entretanto, ainda que a proposta tenha sido enviada a todos, não foi possível atingir a somatória desse público devido a diversos fatores; uma vez que a dinâmica na pandemia é outra, diferente daquela pregressa presencial. De qualquer forma, o material recebido abrange produções de estudantes de $1^{\circ}$ a $9^{\circ}$ ano que compõem um arranjo surpreendente de percursos.

Os alunos participantes realizaram a atividade por meio da plataforma Google Sala de Aula, que constitui a via oficial de comunicação da rede de ensino da cidade de São Paulo na conjuntura de isolamento da pandemia. Para se chegar a esse público, contou-se com a parceria das professoras pesquisadoras Lydia Minhoto Cintra e Glaucia Ribeiro Felipe Cabral, responsáveis pelas disciplinas Sala de Leitura e Artes, na escola Comandante Gastão Moutinho, no âmbito das quais a proposta foi apresentada.

Disparada por uma armação que aciona um território com a arte, a atividade constitui-se de duas etapas. Lança-se mão de quatro ilustrações do quadrinista Rafael Sica, presentes no livro Triste (2019). Sem quaisquer informações ou descrições adicionais, promoveu-se, de largada, um contato dos alunos com as obras. Eles receberam as imagens abaixo, sobre as quais foi solicitado que se debruçassem, despendendo o tempo que julgassem necessário para isso. Tal como feito com os estudantes, faz-se o convite a este encontro a seguir. 
Imagem 1

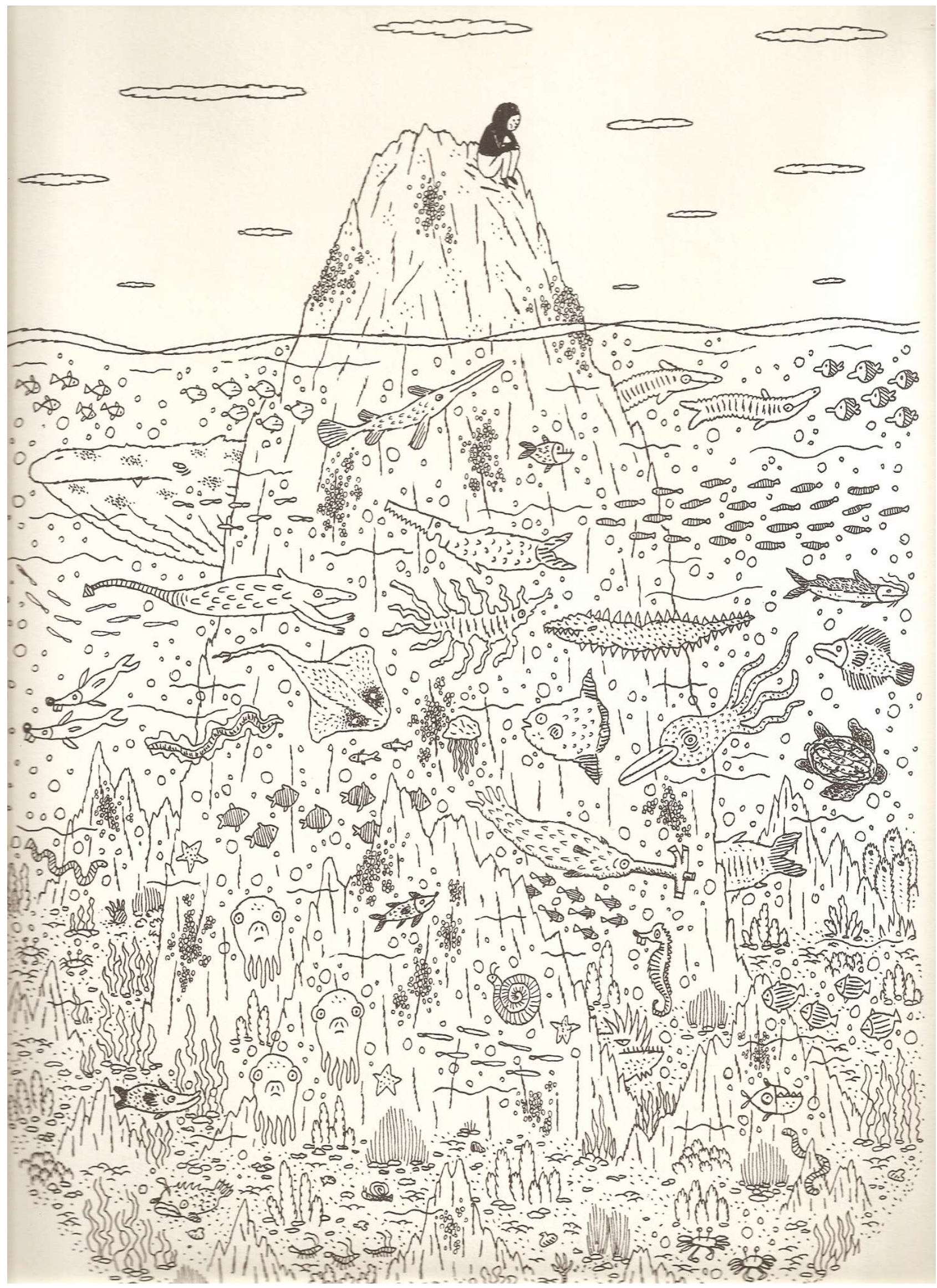

Fonte: SICA, Rafael. Triste. São Paulo: Lote 42, 2019. 
Imagem 2

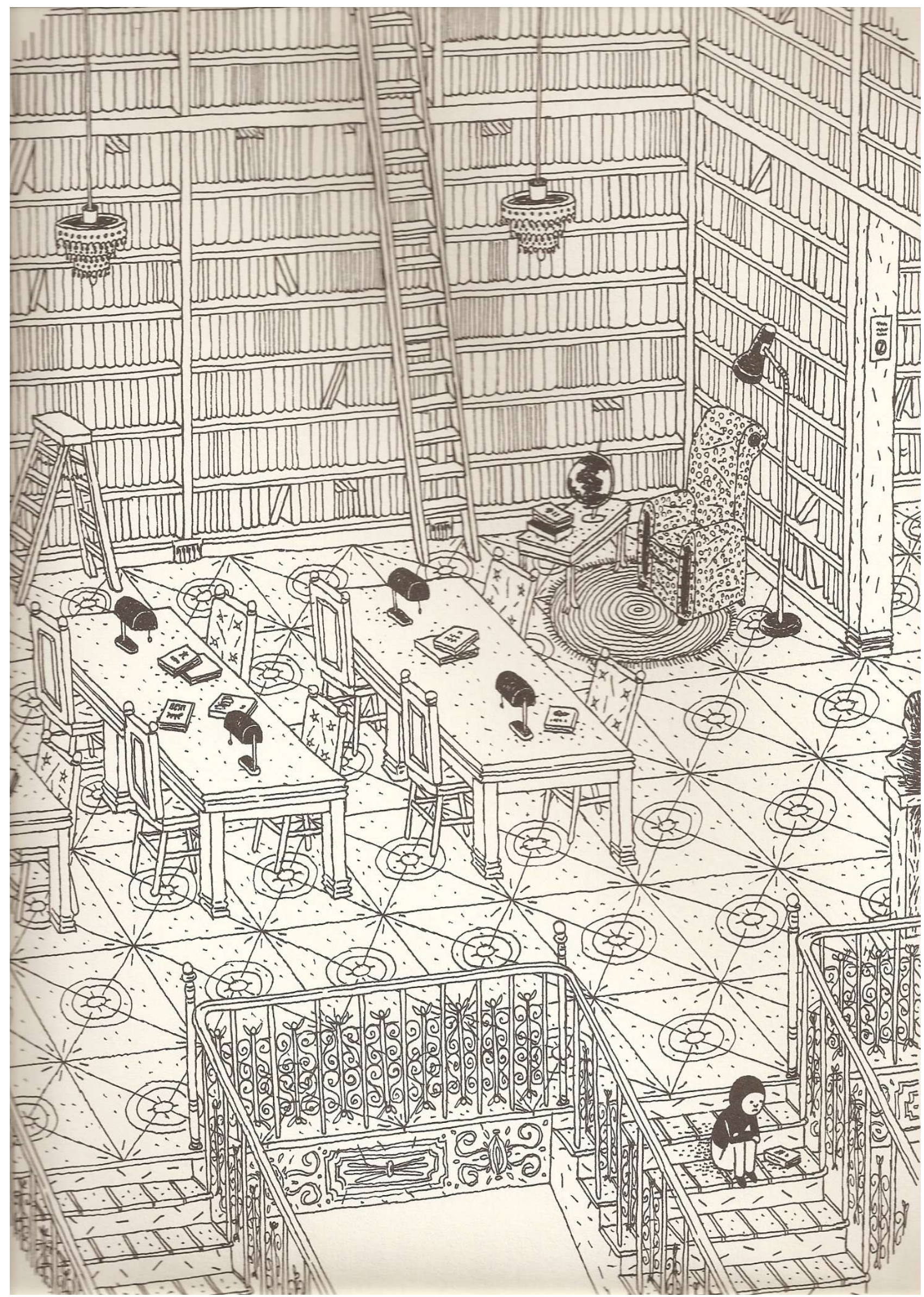

Fonte: SICA, Rafael. Triste. São Paulo: Lote 42, 2019. 


\section{Imagem 3}

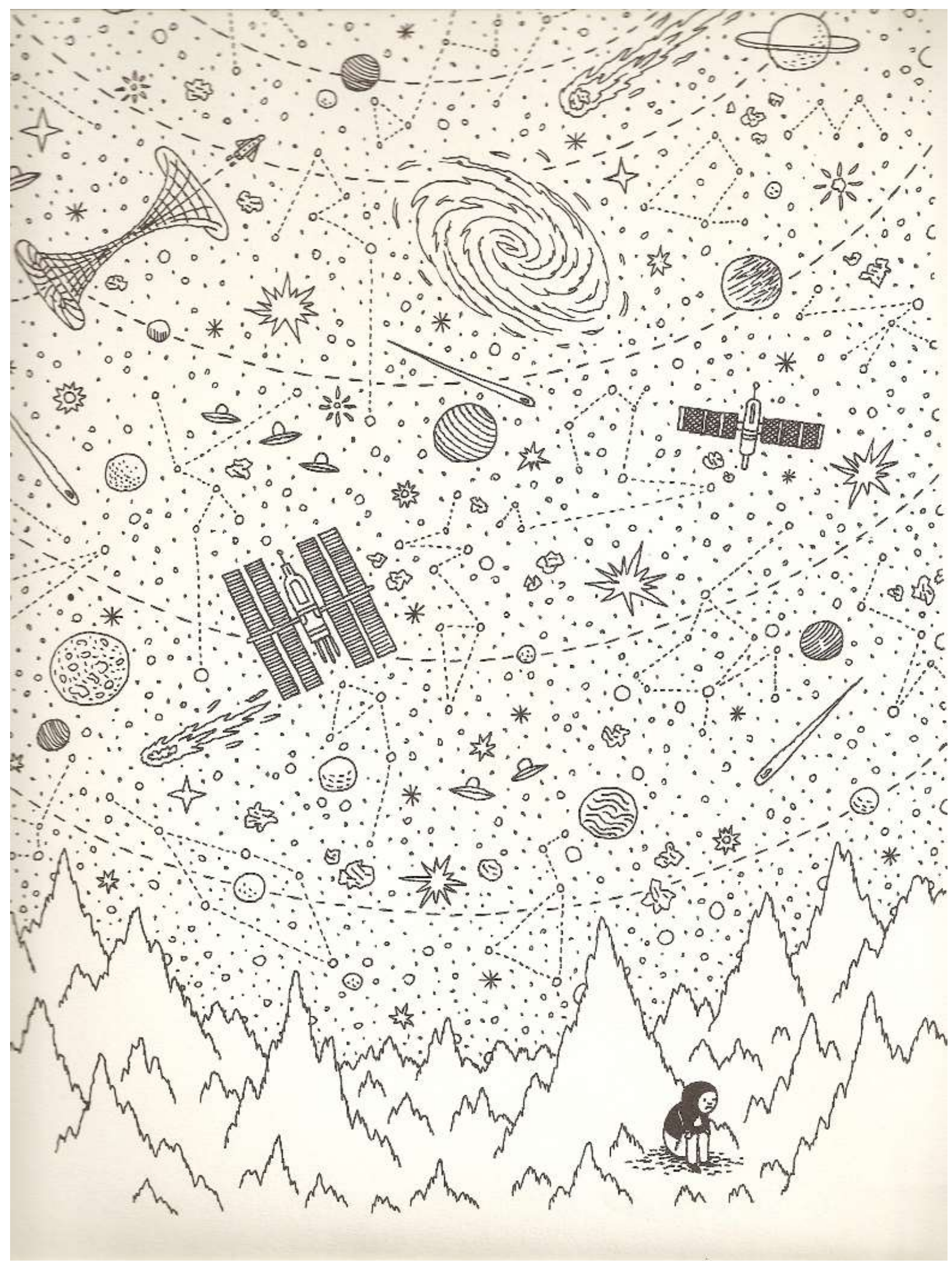

Fonte: SICA, Rafael. Triste. São Paulo: Lote 42, 2019. 
Imagem 4

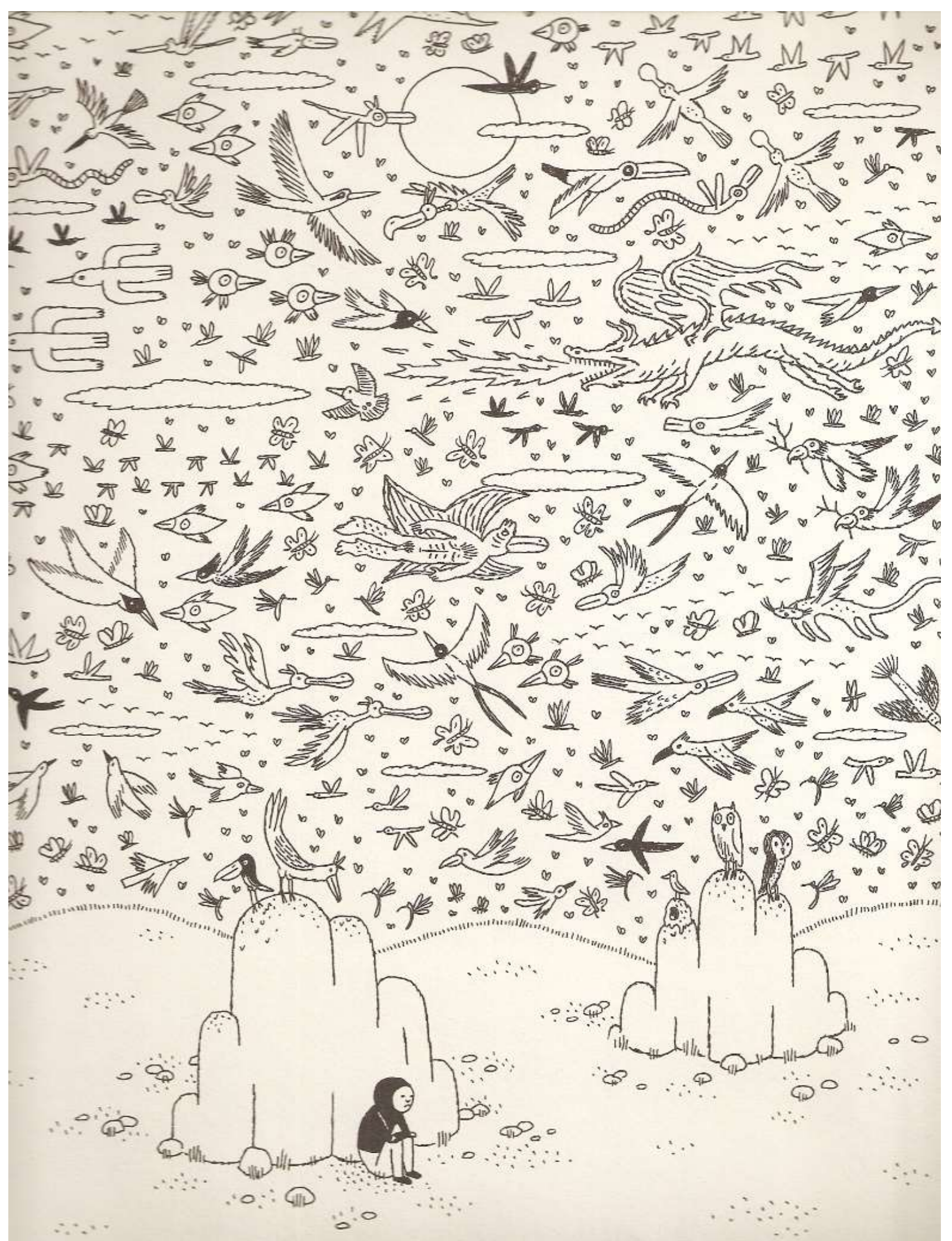

Fonte: SICA, Rafael. Triste. São Paulo: Lote 42, 2019. 
Após o contato com as obras, perscrutaram-se, na segunda etapa, efeitos desses encontros. Para tanto, a atividade interpelou os alunos com as seguintes provocações: o que as quatro ilustrações dão a pensar?; quais sensações e modos de sentir elas produzem? (se é que produzem alguma/algum) ${ }^{5}$. Conforme o contexto pandêmico, a proposta foi desenvolvida a distância; não durante aulas virtuais "ao vivo", mas de modo remoto. Depois de recebê-la, os participantes tiveram cerca de quinze dias para executá-la e encaminhar as produções escritas.

As duas etapas concernem à instauração de um território seguida de uma tentativa de captar como esse momento se passou; jogou-se com a possibilidade de, porventura, incitar movimentos, abrindo espaço, na sequência, à vazão do que pode ter se dado. A iniciativa explora, com isso, o que pode acontecer ao se promover uma experimentação com ilustrações. Tal trama teve o intuito de fazer os alunos escreverem, instigando-os a produzir escrita. E, a fim de desatá-la, tais provocações investigam algum alcance acerca desse contato entre participantes e obras. À vista disso, fazendo-os falar - no caso, escrever -, sondam-se modos de sentir e traçados de percursos de pensamento.

À espreita da possibilidade de entrever atravessamentos, a atividade tem como operador conceitual a perspectiva de afecção ou afecções, presente tanto na produção solo de Deleuze (2002) como em escritos de Deleuze em companhia de Guattari (2010, 2012). Desenvolvida pelo filósofo francês a partir de estudos com o pensamento de Espinosa, ela remete a algo que perpassa mente e corpo ao mesmo tempo, de uma vez, e que ocorre em decorrência de algum contato; trata-se de uma alteração. Com isso, a perspectiva arremata um movimento de contágios e de efeitos, disparado por encontros.

Circunscreve-se afecção diferenciando-a dos termos afeto e afetar-se, pois, diante da gradação variável de intensidade com que pode se dar um atravessamento, ela os excede. Deleuze indica, nesse sentido, certo incremento inerente a ela. "Afecção remete a um estado do corpo afetado e implica a presença do corpo afetante, ao passo que o afeto remete à transição de um estado a outro, tendo em conta variação correlativa dos corpos afetantes" (DELEUZE, 2002, p. 56). Mais do que mera mudança, afecção constitui uma reação a um elemento de fora que age sobre um corpo: um encontro de forças. E um atravessamento no corpo implica, por conseguinte, a mente e o pensamento, já que, por essa vertente teórica, pensa-se com o corpo inteiro.

Além de funcionar como operador conceitual, a tomada de afecções concerne ao crivo pelo qual se acionam as devolutivas dos alunos neste artigo. Ao reunir as produções, montou-se um arquivo com todo o material recebido. Os dados obtidos podem ser trabalhados sob diversos ângulos, sendo este um recorte que se faz dentre outros cabíveis ${ }^{6}$. Esquadrinhou-se, portanto, possibilidades de incidências de

\footnotetext{
5 Tendo em vista efeitos que possam ter se dado, sensações e modos de sentir são termos trazidos em conjunto a fim de indicar atravessamentos pelos sentidos.

${ }^{6} \mathrm{O}$ que pode ser conferido no artigo: $\mathrm{O}$ que a arte dá a pensar: provocações deleuzianas a alunos da rede municipal de São Paulo em meio à pandemia do coronavírus e o que eles têm a dizer sobre isso (SILVA; CINTRA; CABRAL, 2021), Revista Linha Mestra, 2021. Esta produção decorre do trabalho homônimo apresentado pelo trio de pesquisadoras no III Colóquio Variações Deleuzianas: corpo entre Filosofia e Arte e Educação..., realizado via Google Meet, em 24 de novembro de 2020.
} 
afecções, tendo em vista a totalidade deste arquivo. Para tanto, uma leitura apurada permitiu selecionar produções em que tal perspectiva, de alguma forma e em algum grau, vibra.

Porém, antes de compartilhar esses desdobramentos, atenta-se ao movimento inicial propelido. Intentou-se armar, por meio da arte, uma espécie de campo propício a incitar os alunos, considerandoos forças, assim como as imagens; forjaram-se, então, encontros. Não à toa são trazidas à cena da atividade quatro obras de Rafael Sica. Essas ilustrações - como forças reunidas - operam em conjunto, compõem um território, instauram uma ambiência, um jogo próprio a ser experimentado. Por isso se fala em uma experimentação.

Os encontros não se dão exatamente com as obras, mas com a ambiência delas como força. Nesse sentido, a escolha dessas imagens procurou trazer à proposta alguma coisa que paira em Triste (2019), uma aura. As trinta ilustrações que integram o livro perseveram em certa repetição, o que conflagra um tom próprio do desenhista Rafael Sica na confecção da obra. Em vista disso, trabalhar com apenas uma ilustração não daria conta do ambiente do livro, ao passo que trazê-lo na íntegra sobrecarregaria os alunos. Tais liames e detalhes mostram uma contingência necessária para se armar uma cena.

\section{Efeitos da proposta: produções dos alunos e algumas análises}

Esta segunda parte do artigo exibe o que os alunos têm a dizer sobre a experimentação. A partir de uma seleção do material reunido, apontam-se possibilidades de traçados e vislumbres de afecções, em sete enfoques diferentes. De acordo com este recorte, o trato com os dados obtidos os toma como um todo sem, por exemplo, divisões por anos letivos. Estes aparecem nos créditos das produções precedidos pela letra inicial do nome dos estudantes; as falas são referenciadas dessa forma a fim de resguardar os participantes. A este ponto, cabe retomar as provocações que estimularam estes registros: "o que as quatro ilustrações de Rafael Sica dão a pensar?"; "quais sensações e modos de sentir elas produzem?".

\section{1 - Modos indizíveis}

Diante do encontro com a ambiência das quatro ilustrações, a aluna H., do $4^{\circ}$ ano, pontua: "gostei bastante de saber que eu não era a única a sentir isso". Outro aluno, A., do $8^{\circ}$ ano, afirma que o conjunto das quatro imagens traz sensações de paz e solidão e explica: "não penso em uma solidão literalmente. É tipo uma solidão gostosa, não sei, só sei que gosto disso". Destacam-se, nas produções ${ }^{7}$, os termos isso e disso. Os participantes fazem indicações de que se sente alguma coisa e se gosta de algo ("tipo uma solidão gostosa"), mas não as definem; não cerceiam nem represam tais indicativos em fechamentos, apenas anunciam as experimentações.

Algo parece escapar em ambos os casos, ou talvez seja da ordem do incapturável o que neles surge. Tateiam-se, com isso, modos de sentir indizíveis, os quais remetem ao que se sente e se

\footnotetext{
${ }^{7}$ Referimo-nos ao material recebido dos alunos como falas, produções, proposições, dados obtidos, entre outros termos. Todos concernem às devolutivas recebidas a partir do disparo da atividade.
} 
experimenta, em decorrência de atravessamentos, sem o alcance de um rebatimento em palavras, sem dar conta de uma tradução. Aliás, desse jeito, as duas produções ressaltam a abertura da atividade a uma escrita que pode conter o inominável.

Elas favorecem especificar também que, considerando-se os registros dos estudantes, não se pode inferir se houve ou não afecção, de modo taxativo, nas experimentações. A propósito, nem vem ao caso essa determinação, o que seria algo como apontar e localizar: "há afecção aqui"; não há gabarito para verificar isso. Cada escrita é singular, podendo envolver uma zona um tanto indiscernível acerca do que se passou. Por mais que sejam pungentes, atravessamentos podem carrear uma sutileza, um não-dito, pois trata-se de algo, sobretudo, sentido. Logo, ao se acionarem tais produções, fala-se em possibilidades de afecções, já que interessam movimentações que acenam a elas: rastros, traços, vibrações, nuances.

\section{2 - "Imagens tristes sorrindo para nós"}

Outra aluna mira a perspectiva de um encontro de forças propriamente. Sobre a experimentação, L., do $6^{\circ}$ ano, anuncia: "parecem imagens tristes sorrindo para nós porque você acha que não tem muito desenho mas tem. $\mathrm{O}$ menino ${ }^{8}$ acha que está só mas se olhar com outros olhos tem mais do que ele pensa ali". Para a estudante, as obras denotam, de alguma maneira, uma tristeza; contudo, ela assevera que as ilustrações sorriem "para nós". Depreende-se aqui algo além de uma aliança entre um aspecto triste e o ato de sorrir; ultrapassa-se isso. Tal indicação põe em relevo forças das imagens reunidas e a incidência de vida que há nelas. Assim, a aluna parece lidar, justamente, com as próprias imagens. Não se trata mais dela, como participante da atividade, olhando as ilustrações. As imagens é que a estão olhando, e mais, sorrindo para ela. Trata-se de uma reversão de ângulos, de um deslizamento; eis uma repercussão sensível que fez as imagens ganharem um outro lugar, que não remete a uma representação exatamente? .

Ao conclamar uma ação das imagens - elas sorriem "para nós" -, esta produção acena com um desdobramento sagaz da iniciativa. A armação da atividade, pela ambiência e pelas provocações, procura conflagrar uma aproximação das forças em jogo para, quiçá, uma "fazer corpo com"10 outra, compor, contagiar. Posto isso, assinala-se que esta aluna operou de maneira notável com a perspectiva teórica acionada.

Tal fala abre caminho para balizarmos que o delineamento da abordagem teórica fica circunscrito a este artigo. A atividade não fez menção a isso, uma vez que, para os alunos, importava enfocar a experimentação. Valemo-nos dos referencias acionados para confabular a iniciativa, mantendo-os, porém, nos bastidores. Evocados também nas presentes análises, eles são explorados neste outro momento, em que se abordam as produções dos alunos, levando-as a público.

\footnotetext{
${ }^{8}$ Os participantes referem-se ao personagem de diferentes formas, como menina, menino - no feminino e no masculino.

${ }^{9}$ O destaque à produção desta aluna é uma colaboração fornecida pela Profa. Dra. Cintya Regina Ribeiro.

${ }^{10}$ Expressão do universo deleuzo-guattariano referente à discussão de corpo sem órgãos (DELEUZE; GUATTARI, 2011, 2012).
} 


\section{3 - Ilustrações que perguntam}

Visando a força das obras, a própria atividade incorpora uma movimentação na linha da fala desta aluna. Para abordar esse aspecto, é preciso complementar a armação da iniciativa (já apresentada, em linhas gerais). Ela constitui-se, efetivamente, de dez perguntas. Fez-se, primeiro, uma proposta-base cujo cerne são as provocações ${ }^{11}$. A partir daí, estas foram trabalhadas e moduladas em mais questões, dando conta de quatro versões da atividade. Considerou-se, para tanto, os anos letivos, as etapas educacionais e as faixas etárias dos participantes; quais sejam: 1) ciclo de alfabetização - $1^{\circ}, 2^{\circ}$ e $3^{\circ}$ anos, 2) $4^{\circ}$ e $5^{\circ}$ anos, 3) $6^{\circ}$ e $7^{\circ}$ anos, 4) $8^{\circ}$ e $9^{\circ}$ anos. Assim, essas variações buscaram tornar a iniciativa mais próxima a cada grupo de alunos.

Frisa-se uma questão presente nas quatro versões: "imaginando que as imagens lancem uma pergunta, qual seria?". Os alunos, então, dizem: "você também está perdido?" (N., $8^{\circ}$ ano), "você está prestando atenção?" (M. $4^{\circ}$ ano), "quais coisas apareceram na imagem?" (A., $8^{\circ}$ ano), "você consegue me ver?" (A., $7^{\circ}$ ano). A pergunta da atividade exalta um jogo de forças entre alunos e obras, mas não só. Ao demandar um posicionamento, ela promove um giro, enaltecendo a força das ilustrações; estas ganham destaque pela requisição de um movimento que as faz falar. Com isso, um deslizamento se dá porque, dessa vez, quem pergunta não é a proposta nem são (diretamente) os alunos; são as próprias imagens. Sustentando essa suposição, não se trata, nesse caso, de participantes dizendo de encontros com as obras, mas do que as obras dizem - mais do que isso, interrogam.

Segundo essas perguntas(-respostas) selecionadas, as imagens questionam se o aluno/interlocutor também está perdido, se está prestando atenção, o que vê aparecer nelas e, ainda, se o aluno/interlocutor consegue vê-las. Na medida em que há atravessamentos comuns às forças em jogo (alunos e obras), avistam-se rumores de afecções, que se rastreiam conforme as perguntas citadas. Dessa forma, as imagens: 1) insinuam um ambiente ou uma situação, em que alunos e obras estão ou se sentem perdidos; 2) verificam se o participante está atento às ilustrações, o que deixa implícito que elas estão atentas; 3) demandam o que exatamente o estudante está vendo, ou seja, qual é a apreensão de um olhar de fora; e 4) buscam ratificar não apenas se o aluno as vê, mas se consegue fazer isso. Assim, as perguntas lançadas fazem desconfiar que um encontro com tal ambiência, em um enfrentamento que se dá, não consiste em algo trivial. Eis chances de análise.

\footnotetext{
${ }_{11}$ Dada a ambiência, intentou-se que as provocações, bastante sucintas, buscassem enlaçar alguma movimentação nesse ínterim com a mínima interferência possível a fim de não encaminhar direcionamentos interpretativos, relacionados a uma hermenêutica. Ao fim e ao cabo, elas perguntam algo sutil, como se dissessem aos alunos imediatamente após a experimentação: "e, aî?". Aliás, caso a atividade fosse realizada em sala de aula, de forma presencial, talvez essa única interpelação desse conta do que se tenciona.
} 


\section{4 - Composições variadas: o fora e o caos, sensibilidade e territórios do pensar}

Reúnem-se, a seguir, falas que alinhavam o que se passa em dimensões dessa ambiência, focalizando, particularmente, o que ocorre entre duas forças: o personagem e um "fora" - ou o que é extrínseco a ele. Sobre o que as ilustrações dão a pensar, os estudantes declaram: "uma menina que pensa que não tem nada de divertido ou impressionante para fazer, mas ao redor dela tem diversidades de coisas que ela ignora sem perceber" (G., $9^{\circ}$ ano), "o menino se vê sozinho mas não vê o que está de verdade em volta dele" (G., $6^{\circ}$ ano), "que as pessoas não veem mais o mundo ao redor" (M., $5^{\circ}$ ano), "coisas novas, descobertas. Senti que nós podemos apreciar o mundo de uma forma única" (H., $5^{\circ}$ ano), "que quando ela está no oceano ou entre as aves parece que ela está num quarto fechado" (G., $4^{\circ}$ ano). Distribuem-se interposições entre o que se vê e o que não se vê, ou não se pode ver. Entre ver e não ver há um lugar no meio, um "entre", um ângulo que permite fazer tais acenos. Há aí uma triangulação, uma terceira força inserindo-se nessa dinâmica e compondo essa ambiência; os participantes olhando, nas ilustrações, o personagem e o "fora". É dessa montagem (a qual perpassa um território armado nas obras reunidas) que vêm os desdobramentos.

Elencam-se mais produções que, ao se desenrolarem, abarcam um horizonte de um "fora". "[As obras fazem pensar na] vasta dificuldade de entendimento do mundo. A gente não tem o mínimo de noção do que se passa em volta da gente" (F., $9^{\circ}$ ano). "Que no mundo existem muito mais coisas além daqui" (P., $5^{\circ}$ ano). "Coisas inimagináveis que nós, humanos, nem sabemos que existem" (M., $4^{\circ}$ ano). "Que se formos ver o todo, o nosso problema passa a ser muito pequeno" (V., $5^{\circ}$ ano). "[As imagens] me fazem pensar em uma pessoa que só fica presa ao que ela conhece e ao que a faz confortável" (S., $9^{\circ}$ ano). Surgem nas falas lances, embates, suposições, impedimentos, avaliações, alumbramentos.

Este artigo é escrito para isso; dedica-se a exibir esses percursos que mostram um grau de sensibilidade, inclusive, inesperado conforme as faixas etárias dos participantes. As falas apontam a outros universos e à própria vida em ato, fazem ponderações, perspectivações, arremessos vultosos. Essas movências permitem pressupor que, talvez, alguma coisa tenha se passado nessas experimentações. Presume-se que há, nas produções citadas, vislumbres nesse sentido pelas agitações que elas carreiam. Desse modo, tais proposições reverberam a armação da atividade que se empenha em incitar uma tensão, fazendo, quem sabe, de encontros com a arte territórios do pensar.

Nestas últimas falas citadas parece haver incidências de intensidade, um vigor, um pulso. No que tange às movências, tomando-as de forma mais apurada, abordam-se pistas de expansões e compressões: (uma) vasta dificuldade, (um) mínimo de noção, muito mais coisas além daqui, coisas inimagináveis, ver o todo, ficar preso e confortável. Eis uma amostra pontual, todavia, de maneira mais ampla, a união das produções trazidas aqui assinala uma modulação de intensidades presente; o "conjunto da obra" das falas acena uma miríade de atravessamentos. Infere-se com isso que afecções abrangem tanto contágios efetivos de forças em jogo - mais viscerais, de impacto - como contatos menos intensos, 
nos quais, de qualquer modo, algo acontece, no sentido conceitual deste termo ${ }^{12}$. Mas, para tanto, reiterase, há encontros de forças.

Os alunos e o "fora": a experimentação, a ambiência, as obras, a atividade. O personagem e o "fora": os lugares, os elementos e as vidas ao redor. Um "fora" cinge um corte na circunstância em que se está - na ocasião, na situação -, instaura uma fenda, abre uma fresta; nos termos de Deleuze e Guattari, pode-se falar em um corte no caos (2010). Nessa trilha, Deleuze defende que o pensamento precisa fazer encontros com o fora, os quais podem ser potentes ou não, disparar ligações ou não. Há aí tentativas, experimentações. Para tanto, segundo o filósofo francês, o pensamento deve aliar-se ao que o fomenta.

Esses encontros não se dão propriamente conforme consonâncias e acordos; pelo contrário, abrangem um jogo de movimentações. Nessa chave, fala-se sobre fazer violência com o pensamento (DELEUZE, 1987), o que nada mais é do que insistir nesse ato, percorrer pistas, rastrear estímulos. Tal modo de pensar não converge a fechamentos pré-determinados, mas a aberturas; constitui algo vivo. E tecendo-se em encontros, o ato de pensar está atrelado a uma dimensão sensível, envolve algo que é sentido, o que pode se dar por alguma coisa com a qual se depara; por isso se trata de uma ação que se faz com o corpo todo. Tendo em vista o encontro com o "fora" como algo que atravessa, pode-se aproximar o ato de pensar para Deleuze da perspectiva das afecções.

Nesse sentido, ao perscrutarem modos de sentir e sensações ${ }^{13}$ e o que as ilustrações fazem pensar, as provocações miram, nos bastidores da proposta, o ato de pensar pela perspectiva deleuziana. As perguntas incluem a possibilidade de se dispararem outros lances. Assim, a atividade não requer que algo seja compreendido e demonstrado; ela enaltece a experimentação. À vista disso, realça-se que essa experimentação não é da ordem do entendível. Encontros e atravessamentos a partir daí podem arrastar modos de sentir, oportunizando essa perspectiva deleuziana de pensar. E se as produções partilham percursos vivos e traçados tais que desenvolvem agitações, o ato de pensar nesse enfoque pode se dar nesses movimentos.

Inclusive, é curioso notar as produções que dizem da "vasta dificuldade de entendimento do mundo" e de "uma pessoa que só fica presa ao que ela conhece". Tem-se um entendimento e um conhecer que são perpassados. Depreende-se um atravessamento em um modo de sentir que remete à "vasta dificuldade de entendimento do mundo", o que, da mesma forma, não é da ordem do entendível. Ao passo que encontros e atravessamentos seriam uma via para rebater "um estado" de "só ficar preso ao que se conhece". Outra fala traz a combinação entre pensar e sentir: "As imagens passam um sentimento de tristeza, parece que algo de muito ruim aconteceu e a personagem precisa parar pra entender como

\footnotetext{
${ }^{12}$ Referimo-nos ao termo acontecimento na perspectiva deleuziana, como uma mudança de nível, uma ocorrência incapturável (ZOURABICHVILI, 2016).

${ }^{13} \mathrm{O}$ termo "modos de sentir" está articulado ao referencial teórico da proposta, abordado neste artigo. A atividade, no entanto, não traz essas referências aos alunos, apenas enfoca a experimentação e as provocações. Posto isso, apresenta-se essa pergunta, que contém o termo aqui explicitado, mas não utilizado com os alunos na atividade; valemo-nos de outras formas de dizer isso mais próximas a eles.
} 
tudo isso aconteceu" (A., $7^{\circ}$ ano). No caso, "parar para entender", como disse a aluna, abrange o atravessamento do que se passou, o que envolve uma tristeza em alguma medida.

\section{5 - "Eu sinto a tristeza subindo": experimentação em vez de interpretação}

Para avançar com as falas, acresce-se mais um bastidor da armação da proposta. No disparo da atividade não foi mencionado aos alunos que as ilustrações integram um livro intitulado Triste. Tal informação só foi fornecida a posteriori, quando as produções escritas já tinham sido enviadas. Suspendeuse (oportuna e) temporariamente esse detalhe porque ele poderia exercer influência, fazendo talvez com que se incorresse em interpretações prévias. Se revelado de largada, o título poderia ser tomado como um índice ou um indicador de uma forma de ler ou de fazer a atividade, ou ainda como uma legenda do personagem; ao ocultá-lo, evitou-se qualquer aderência com termo "triste".

Esse cuidado foi tomado a fim de assegurar um percurso na trilha de uma filosofia da imanência. A propósito, a armação da atividade vai de encontro a vieses interpretativos. Não se busca pelo que as imagens "querem dizer" e não se conta com percursos prévios, preestabelecidos a se percorrer. O enfoque fica por conta da experimentação. Para tanto, as provocações consistem em perguntas abertas a territórios forjados pelas quatro obras. E assim como não interessam interpretações, também não há respostas certas ou erradas a essas perguntas; há apenas respostas. Inclusive, vale realçar que as disciplinas nas quais a atividade foi realizada têm a prerrogativa de ser desvinculadas de avaliação, não têm o compromisso de aferir nota e rendimento.

Parece que tal medida quanto ao título funcionou. Ao se questionar "quais sensações e modos de sentir as ilustrações produzem?", os alunos afirmam: "contemplação" (H., $5^{\circ}$ ano), "[sensações] de cuidado com os seres e coisas" (E., $8^{\circ}$ ano), "sentimento de bem-estar" (K., $7^{\circ}$ ano), "sensação de tranquilidade" (G., $8^{\circ}$ ano). Colecionam-se apreensões variadas sobre essa provocação, que não necessariamente afluem a um único denominador comum pertinente à tristeza, ainda que esse enfoque também tenha sido pontuado, como mostraremos a seguir e como nos traz esta aluna: "há um sentimento de tristeza por ver ela isolada em lugares tão bonitos" (G., $9^{\circ}$ ano).

Na sondagem acerca de sensações e modos de sentir, desponta uma tendência. Alunos pontuam: "[o conjunto das obras] me passa um sentimento misturado" (C., $2^{\circ}$ ano), "sentimento de dúvida" (P., $2^{\circ}$ ano), "sentimento de confusão" (J., $6^{\circ}$ ano), "confuso" (M., $5^{\circ}$ ano), "sentimentos misturados, bons e confusos" (V., $3^{\circ}$ ano), "agonia" (B., $9^{\circ}$ ano), "triste, solitário, pensativo, misturado bom e ruim" (E., $1^{\circ}$ ano), "a tristeza de estar sozinha e a calmaria de estar em silêncio. São sentimentos misturados" (S., $9^{\circ}$ ano). Sobre o que as imagens fazem pensar, P., do $7^{\circ}$ ano, aponta: "ele está em um lugar lindo mas está em um canto triste". Delineiam-se vertentes díspares.

Há uma produção, seguindo nesse horizonte, que parece desdobrar ainda mais essa trilha. Pondo em vizinhança diferentes aspectos, a aluna L., do $6^{\circ}$ ano, e o aluno A., do $5^{\circ}$ ano, fazem a mesma proposição, qual seja, que a ambiência das obras proporciona um "sentimento de alegria e tristeza". Tem- 
se, assim, alegria e tristeza de uma vez, em um só golpe, o que condiz com uma ultrapassagem, pois a dupla de participantes não as referenciam de forma apartada, estanque, uma coisa ou outra; os estudantes amarram uma coisa e outra coisa. Logo, alegria e tristeza performam juntas, em aliança, o que entoa um modo próprio de sentir, singular, um bloco de sensações ${ }^{14}$.

Justapor uma força a outra, compondo-as pelo "e", faz lembrar as perspectivas deleuzianas e deleuzo-guattarianas de rizoma e do enredamento pelo "e, e, e" (DELEUZE; GUATTARI, 2011). Como indica François Dosse, biógrafo da dupla de autores, tem-se no "e" a possibilidade de criação e a multiplicidade (DOSSE, 2010). Há nessas junções da dupla de alunos, por conseguinte, um viés inventivo importante ligado à aliança; unir uma força a outra, formando outras, o que se dá à medida que os estudantes tratam também de algo que se passa entre eles e as obras.

Desta particularidade, passamos a tomadas mais amplas com o material reunido. Ao vasculhar, nas falas, conexões que se repetem, nota-se que sobrassem manejos referentes à solidão e à tristeza, cujas abordagens se dão de modos múltiplos, tal como enreda L., do $5^{\circ}$ ano: "me fez pensar que ficar sozinho não é bom para ninguém e senti tristeza porque muitas pessoas são sozinhas". Logo, independentemente da proposta da atividade não revelar o título do livro, boa parte dos alunos ${ }^{15}$ convoca limiares de tristeza, flagrada na ambiência das ilustrações. Nesse sentido, ao se efetuar uma apuração pela perspectiva de afecções, ela desponta de forma incisiva, como apontam outras produções.

P., do $5^{\circ}$ ano, a partir das provocações, anuncia: "me faz pensar que a gente não pode viver na tristeza"; M., também do $5^{\circ}$ ano, declara: "eu sinto a tristeza subindo". As falas trazem enfrentamentos da tristeza, em encontros nos quais ela surge viva. A última trata de uma movimentação perpassando o corpo; sendo assim, a tristeza não é apenas sugerida, ela acontece em um desdobrar, espraiando-se. Está em jogo uma mudança de estado, uma alteração, como um efeito das obras em que a transitoriedade se faz presente, o que se aproxima de afecções. Já a primeira recusa o que seria um estado de tristeza, defendendo que não se pode viver nele. Atenta-se que, para refutar a tristeza com o argumento de que não se pode viver nela, é preciso perpassá-la, atravessá-la, ter uma experimentação desse modo de sentir.

Esses lances oportunizam relatar nosso próprio encontro com a obra, em 2019. Triste nos fisgou pela capa, na bancada da editora Lote 42, na Festa do livro da USP ${ }^{16}$, e nos fez parar. Capa e contracapa formam uma árvore; para isso, é preciso abrir o livro. Ao folheá-lo, algo aconteceu; os desenhos nos capturaram. Adquirido um exemplar, continuamos observando as ilustrações com o passar do tempo. Algo nelas, notadamente, pedia passagem; alguma coisa continuava acontecendo, um enigma. Face aos efeitos das ilustrações em nós e o contágio nesse encontro, quisemos levá-las a outras pessoas, o que

\footnotetext{
${ }^{14}$ Deleuze e Guattari falam de bloco de sensações ao tratarem de perceptos e afectos, na trilha discussão que aborda afecções (DELEUZE, GUATTARI, 2010).

${ }^{15}$ No trato com o material, optou-se por não fazer análises quantitativas, que mensuram números ou porcentagens. Trabalhase com tomadas que consideram quantidades gerais; por isso fala-se, por exemplo, em "boa parte". A fim de não esquadrinhar nem focalizar números em minúcias, prefere-se a isso tons e nuances mais vastos dos dados obtidos, tendo em vista um parâmetro que os abarca como um todo.

${ }^{16}$ Evento anual que reúne editoras no campus São Paulo da universidade, com descontos atrativos em parte das publicações.
} 
propiciaria inquirir como essa experimentação se passaria. O contato com a obra suscitou, sobretudo, uma suspeita que não nos abandonava: Rafael Sica parece transtornar apreensões mais óbvias do que acontece em cada cena; o que se confirmou nas produções dos alunos de uma maneira impensável.

Essa desconfiança aproxima-se de falas já citadas, que são trazidas agora em composição: "parecem imagens tristes sorrindo para nós porque você acha que não tem muito desenho mas tem", "quais coisas apareceram na imagem?", "você consegue me ver?", "você está prestando atenção?". Conjectura-se, com elas, que há nessa ambiência mais do que se supõe. À vista disso, infere-se que muitas das produções não tratam de associações óbvias; algumas trazem modulações bastante singulares. Pelo fluxo de falas como "eu sinto a tristeza subindo", "sentimento de alegria e tristeza", "me faz pensar que a gente não pode viver na tristeza", a tristeza é transmutada, atuando com outras forças, o que vai ao encontro de nossa suspeita com Triste.

\section{6 - Solidão}

Outra conexão que se repete no material reunido concerne a manejos referentes à solidão. Parte dos alunos alude à temática ou aponta, especificamente, que o personagem está sozinho. "As imagens me passaram um pensamento de solidão em um lugar tão vago e cheio de coisas para explorar" (N., $9^{\circ}$ ano). "Fazem pensar que mesmo se tivesse sozinho no mundo, ainda não estaria completamente sozinho" (B., $9^{\circ}$ ano)."Me lembra do quão bom é ficar sozinho" (A., $8^{\circ}$ ano). "Para poder pensar sobre tudo que está acontecendo nessas imagens precisa estar sozinho no silêncio" (M., $6^{\circ}$ ano). "É como se ele estivesse se preparando para o mundo porque tem tanta coisa para ele explorar, se aventurar, para ele não se sentir sozinho, mas ele busca sempre a sua solidão" (B., $9^{\circ}$ ano).

A questão de ficar só e um estado de solidão aparecem em diversas entradas; ora aliam-se a um ato de explorar, em um enfrentamento, ora pactuam com uma introspecção e uma preparação para, também, fazer frente ao "fora", encarar o mundo. Algumas dessas falas armam contraposições, outras, inclusive, colocam em xeque a possibilidade de, efetivamente, ficar sozinho. E se há rebatimentos a esse estado de solidão - em que não se cerca com nada e há uma ausência ao redor -, esta situação, por outro lado, também é algo que se busca. Trata-se, enfim, de abordagens que podem perpassar corpo e mente.

Dentre as produções que remetem a este assunto, tendo em conta todo o material reunido, notam-se duas afluências que se alargam: a solidão vinculada à situação pandêmica e ao uso de tecnologia, incluindo, sobre esta última, a relação entre natureza e tecnologia. Com isso, sobre o que as obras dão a pensar, quatro estudantes afirmam: "essas imagens me fazem pensar em tudo que estamos vivendo" (G., $6^{\circ}$ ano), "diz sobre isolamento e sobre não ter mais sentido na vida" (A., $7^{\circ}$ ano), "fala do homem estar só, longe de toda tecnologia moderna, num mundo onde quem tem a liberdade são os animais" (K., $4^{\circ}$ ano), "que sem internet nós percebemos o que está a nossa volta" (F., $5^{\circ}$ ano). Nestas últimas falas, é a 
questão do isolamento que surge associada à tecnologia, remetendo à falta de liberdade e a uma desconexão com o mundo ao redor ${ }^{17}$.

À vista dessas conexões todas que despontam até aqui, tece-se uma análise que atenta à armação da proposta. Ao olhar para uma imagem, outra imagem, outra e outra, todas mantêm o personagem em uma mesma condição, independentemente do local em que ele se encontra. Existe aí uma recorrência de jogadas que pode fazer com que algo salte. Em outras palavras, ao olhar para as quatro telas, alguma coisa pode estar acontecendo que também concerne a um jogo de repetições; este pode ser explorado pela disposição do conjunto em cena, lado a lado, o que arma um cenário de confluências para além de uma única ilustração e que, contudo, funciona também como ocasião para saídas disruptivas ${ }^{18}$.

\section{7 - "Eu prefiro não", "achei essa lição muito triste"}

Coteja-se, por fim, rastros da perspectiva de afecções em efeitos de reação à própria proposta. Sobre o que a ambiência das obras faz pensar, o aluno G., do $4^{\circ}$ ano, declara: "pode dar a oportunidade de reparar em pequenos detalhes que o mundo tem. Achei essa lição muito triste e eu não quero nunca ficar sozinho no mundo". Aos manejos referentes à tristeza e à solidão, soma-se este de enfática recusa. Em nenhum momento a iniciativa interrogou, especificamente, o que os participantes achavam dela. Este aluno, no entanto, se posiciona sobre um desconforto decorrente do desdobramento da proposta. A rejeição traz a desconfiança de um atravessamento, já que essa fala incisiva se dá sobre um conflito.

$\mathrm{Na}$ trilha de uma filosofia da imanência, salientam-se encontros cujos efeitos são da ordem do imponderável. Não se poderia prever a repercussão com os estudantes antes da atividade ser, de fato, disparada, o que reafirma a consecução da proposta como uma aposta, um jogo de dados. Bancou-se um risco de coisas acontecerem ou não, em um deslocamento no campo educacional, frequentemente cerceado por perguntas que já tem respostas prévias prontas. Devido a essa premissa teórica que se faz um adendo às provocações. Ao demandarmos o que as quatro ilustrações dão a pensar e quais sensações e modos de sentir elas produzem, complementa-se (esta última): "se é que produzem alguma/algum". Tal asserção assegura que faz parte do jogo não acontecer nada, o que não é o caso, por exemplo, da última produção citada, que traz um incômodo, indicando que algo se passou.

Para seguir nessa linha, apresentamos outra pergunta que integrou a atividade especificamente nas versões aplicadas aos alunos de $1^{\circ}$ a $5^{\circ}$ ano: "o que você diria ao personagem das ilustrações?". O aluno M., do $4^{\circ}$ ano, alerta: "se anima, cara, olhe tudo ao seu redor, olhe o mundo. Nós somos tão abençoados que nós não damos valor ao que temos e às vezes não enxergamos a beleza do mundo". Já a aluna M., do $5^{\circ}$ ano, declara: "eu não ia falar nada". As duas falas são colocadas lado a lado para

\footnotetext{
${ }^{17}$ Sublinha-se que não foi indicado, na atividade, nenhum viés temático ou qualquer tipo de direcionamento de abordagem. Da mesma forma, tendo em vista a conjuntura em que a proposta foi aplicada, não foi premeditado qualquer elo entre as obras e o isolamento referente à pandemia. Como exibido acima, parte dos alunos fez conexões com a temática da solidão e, alguns dentre eles, à circunstância pandêmica.

${ }^{18}$ Este trecho traz mais uma colaboração fornecida pela Profa. Dra. Cintya Regina Ribeiro a este trabalho.
} 
contrapor os lançamentos da primeira à recusa da segunda que, inclusive, lembra a frase "eu prefiro não", do personagem Bartleby, o escrivão (2017) de Herman Melville. A negativa da aluna sugere que este, talvez, possa ser um caso em que não houve efeito a ser desdobrado pelo encontro de forças.

O conjunto das falas selecionadas mostra também um desafio implícito nesses encontros, que se conecta ao operador conceitual da proposta. Isso porque, sendo agradável, atraente, instigante ou não, os participantes enfrentam as obras e depois as provocações. Não obstante, esta é uma atividade simples; fomenta-se um território em que eles podem se imiscuir às ilustrações. Tal envolvimento fica latente em outras falas da última aluna citada quando ela responde as provocações. M., do $5^{\circ}$ ano, após dizer "eu sinto a tristeza subindo", adiciona: "assim que as pessoas veem a tristeza não tem como escapar dela". Ou seja, a participante opta por não dizer nada diretamente ao personagem, contudo registra um efeito vivo do encontro com a ambiência ao indicar que sente a tristeza subindo, assim como aborda um confronto com ela. $\mathrm{Na}$ esteira desse enfrentamento, outro aluno, A., do $4^{\circ}$ ano, pontua: "Tristeza é inevitável. Achei interessante, pensei que não vale a pena virar as costas para o mundo, algumas vezes me senti dentro das imagens."

Ainda sobre a armação da proposta, inevitavelmente ao executarmos tal iniciativa, tangenciamos certo imperativo pedagógico, pois a atividade consiste em um convite, mas também em uma obrigação. Ela é aplicada no âmbito escolar, remetendo, com isso, a algo que precisa ser feito, resolvido. Ponderamos algum constrangimento nesse sentido, uma vez que ela não é lançada, por exemplo, a voluntários dispostos a participar dela. Solicitando que fosse cumprida, a submetemos aos alunos, incluindo a requisição de que ficassem diante das obras e dessem espaço para esse contato, o que concerne a uma contingência necessária a esta proposta, em que é preciso forçar o olhar, instalar uma tensão. Realça-se a insistência para essas ações, sendo prazerosas ou desconfortáveis. Embora tal disposição seja um pouco impositiva, ela abre caminho a possibilidades de afecção.

\section{Considerações finais}

Ao instaurar uma ambiência com quatro ilustrações de Rafael Sica e lançar provocações, a atividade apresentada busca dar vazão ao que pode despontar e pedir passagem face à contingência desses encontros. Dada a experimentação com as imagens, o intuito da proposta foi desdobrá-la conforme o que se passou, interpelando os 150 alunos de $1^{\circ}$ a $9^{\circ}$ ano e fazendo-os produzir escrita. Considerando-se que as produções dos estudantes dizem, em alguma medida, das experimentações que tiveram, este artigo compartilha a agitação viva dessas falas a fim de difundir o que elas vertem e potenciais que carreiam. "Me faz pensar que a gente não pode viver na tristeza". "Eu sinto a tristeza subindo".

Entre recortes possíveis do material reunido, fez-se uma seleção na qual vislumbra-se certo tilintar de afecções. Sem respostas certas e erradas, em vieses interpretativos, ou pontos de chegada preestabelecidos a se perseguir, a iniciativa articula um espaço envolvendo arte e pensamento, este tomado pela perspectiva deleuziana. Nesse sentido, ao enaltecer a experimentação, a proposta mostra 
como encontros com ilustrações podem mover territórios do pensar. Para tanto, a partir de uma filosofia da imanência, a armação da atividade procurou asseverar uma abertura a encontros a fim de que os alunos, como forças, pudessem se imiscuir às forças das imagens. Sendo que estas perguntam: "Você está prestando atenção?"; "Você consegue me ver?".

Os percursos das falas mostram um grau de sensibilidade surpreendente e, inclusive, inesperado conforme as faixas etárias. As produções partilham percursos vivos de modos de sentir; acenam também com modos de sentir indizíveis e modulações singulares. A partir de muitas delas, pode-se inferir que algo aconteceu nesses encontros - atravessamentos, contaminações de forças. Logo, reverbera em algumas dessas tessituras o ato de pensar, tal como defende Deleuze. No mais, as produções falam por si mesmas - pelo que carreiam, como um verbo intransitivo - e poderiam apenas ser compartilhadas. Todavia, as trazemos neste artigo acompanhadas de algumas análises, o que dá seguimento ao percurso da própria iniciativa, desdobrando-a com a presente escrita. Em tempos escusos de extrema incerteza, insegurança e dificuldade, esta atividade propôs a possibilidade de manejar modos de sentir, instigar o ato de pensar e, a partir disso, produzir escrita. "Parecem imagens tristes sorrindo para nós". 


\section{REFERÊNCIAS}

DELEUZE, Gilles. Proust e os signos. 2.ed. trad. Antonio Piquet e Roberto Machado. Rio de Janeiro: Forense Universitária, 1987.

DELEUZE, Gilles. Espinosa: filosofia prática. Trad. Daniel Lins e Fabien Pascal Lins. São Paulo: Escuta, 2002.

DELEUZE, Gilles. A imanência: uma vida... Educação \& realidade, Porto Alegre, v. 27, n. 2, jul.dez. 2002a. p. 10-18. Disponível em:

<https://seer.ufrgs.br/educacaoerealidade/article/view/31079/19291/> Acesso em: 21/11/2020.

DELEUZE, Gilles; GUATTARI, Félix. O que é a filosofia? 3a ed. São Paulo: Editora 34, 2010.

DELEUZE, Gilles; GUATTARI, Félix. Mil platôs: capitalismo e esquizofrenia 2. Vol. 1. 2a ed. São Paulo: Editora 34, 2011.

DELEUZE, Gilles; GUATTARI, Félix. Mil platôs: capitalismo e esquizofrenia 2. Vol. 3. 2a ed. São Paulo: Editora 34, 2012.

DOSSE, François. Gilles Deleuze \& Félix Guattari: biografia cruzada. Porto Alegre: Artmed, 2010. MELVILLE, Herman. Bartleby, o escrivão: uma história de Wall Street. São Paulo: Editora Ubu, 2017.

SICA, Rafael. Triste. São Paulo: Lote 42, 2019.

SILVA, Lilian dos Santos; CINTRA, Lydia Minhoto; CABRAL, Glaucia Ribeiro Felipe. O que a arte dá a pensar: provocações deleuzianas a alunos da rede municipal de São Paulo em meio à pandemia do coronavírus e o que eles têm a dizer sobre isso. In: Revista Linha Mestra. Ano XV No 44, p. 169-180,

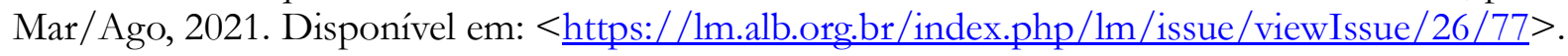

VINCI, Christian Fernando Ribeiro Guimarães. Deleuze-Guattarinianas: experimentações educacionais com o pensamento de Gilles Deleuze e Félix Guattari (1990-2013). 2014. Dissertação (Mestrado em Educação) - Faculdade de Educação, Universidade de São Paulo, São Paulo, 2014. Disponível em: <http://www.teses.usp.br/teses/disponiveis/48/48134/tde-01042015-134108/>. Acesso em: 20/02/2021.

VINCI, Christian Fernando Ribeiro Guimarães; RIBEIRO, Cintya Regina. A difusão do pensamento de Gilles Deleuze na educação brasileira: esboço de um mapa. In: $2^{\circ}$ Congreso Latinoamericano de Filosofía de la Educación, 2013, Montevideo. Anais del $2^{\circ}$ Congreso Latinoamericano de Filosofía de la Educación, 2013.

ZOURABICHVILI, François. Deleuze: uma filosofia do acontecimento. São Paulo: Editora 34, 2016. 